\title{
Blended learning: its implementation and promote continuing e-learning environment among student-teachers
}

\author{
Noraini Mohamed Noh*, Kung-Teck Wong, Mohd Azli Yeop, Norazilawati Abdullah
}

Universiti Pendidikan Sultan Idris, Malaysia, Tanjung Malim, Malaysia

\section{A R T I C LE IN F O}

\section{Article history:}

Received 15 August 2016

Received in revised form

19 October 2016

Accepted 29 October 2016

\section{Keywords:}

Blended learning

Learning management system

E-Learning

Student-teachers

\begin{abstract}
A B S T R A C T
The aim of this paper is to understand and to explore the implementation of blended learning among student-teachers in Sultan Idris Education University (UPSI). UPSI has implemented blended learning via MyGuru and IMS platforms. Under the platforms, student teachers are able to perform EPortfolio, E-Assessment, E-Quiz, E-PBL and etc. Besides, the paper also focuses on how far MyGuru and IMS in UPSI are complying with the ELearning Framework as E-Learning Tools and promote blended learning among adult learners especially student teachers. A case study approach drawing on a phenomenological perspective was carried out in this research. The research has conducted in-depth interviews with students and lecturers to understand and explore their individual perception on the implementation of blended learning in teaching and learning among student teachers.
\end{abstract}

(C) 2016 The Authors. Published by IASE. This is an open access article under the CC BY-NC-ND license (http://creativecommons.org/licenses/by-nc-nd/4.0/)

\section{Introduction}

Technology in higher institutions has now taken a place in the agenda of international meetings, along with trade and economics. Ken Wasch, the President of Software and Information Industry Association (SIIA) in International Society for Technology in Education (2004), stated that technology in education is critical to ensure that all students gain $21^{\text {st }}$ century skills necessary for success by engaging them in the learning process. Information and communications technology has provided tools to help in the teaching and learning processes. Songkram (2015) remarked that the growing importance of education is a new international development because every sensible leader recognizes that the economic, social and cultural wealth of a nation in the Information Age lies in its people, and what they know and can do. In the technological trends of the $21^{\text {st }}$ century, all member countries of the South East Asia Ministers of Education Organization (SEAMEO), including Malaysia, have begun to focus on benefit of information and communications technology to improve the teaching and learning of certain subjects.

\footnotetext{
* Corresponding Author.

Email Address: noraini.mn@fppm.upsi.edu.my (N. M. Noh)

https://doi.org/10.21833/ijaas.2016.11.003

2313-626X/C) 2016 The Authors. Published by IASE

This is an open access article under the CC BY-NC-ND license

(http://creativecommons.org/licenses/by-nc-nd/4.0/)
}

Thus, Malaysian higher institutions have devoted considerable resource to technology. Malaysian higher institutions have included computer technology as an integral part of students learning experiences and as a way to equip them with the skills and knowledge necessary to succeed in the $21^{\text {st }}$ century. In line with that, Universiti Pendidikan Sultan Idris (UPSI) has implemented e-learning method via MyGuru and IMS recently. E-learning is the delivery of instructional content through electronic which include Internet, intranets, satellite broadcasts, audio tapes, video tapes and conferencing, virtual classrooms, digital collaboration and CD-ROMS (Alammary et al., 2014).

According to Glenn and Carrier (1989), the last decade has seen unprecedented growth in the amount of technology available in educational institutions and thus, issue concerning the implementation process has become a focus. Implementation of E-learning technologies involves the careful assessment of numerous factors, such as hardware, software, budgetary decisions, support services and user attitudes, competencies and participation.

E-learning in Malaysia became much stronger and vital in Malaysian education system after the introduction of Smart School. The Smart School is one of the seven flagships applications underlying Multimedia Super Corridor (MSC) which began its operations in 1997. Moreover, the Malaysian government has established various institutions, such as the National Information Technology Council (NITC), the Malaysian Institute of Microelectronics 
Systems (MIMOS), the Communications and Multimedia Commission (CMC) and the Multimedia Development Corporation (MDC) (Tipton, 2002) to encourage the use of computer related technologies in the Malaysian society. Hence, billions of Ringgits have been poured into the educational sector to acquire necessary equipment. Funding efforts over the past few years have dramatically increased the availability of e-learning technology for all higher institutions across Malaysia such as UPSI.

In UPSI, there is widespread recognition that Elearning can play a powerful role in supplementing and complimenting the process of teaching and learning activities among graduates in UPSI but unfortunately at the same time, there is also growing concern that many academic staff lack in either experience or skills that are needed to integrate this new technology (E-learning) in their teaching and learning activities. Besides that, students in UPSI also are reluctant to use MyGuru in their process of learning. So, it is vital to identify the root of the problems in this issue by via comprehensive approach to program evaluation in E-learning program under E-leaning Framework by Khan (2004).

The following discussion will identify how far our e-learning program in UPSI is complying with the Elearning Framework by Khan which has been recognized by many leading universities in the world. Khan (2004) noted that there is always room for improvement by exploring what works and what did not. To understand online learning environment, we need to have a comprehensive picture of people, process and product involved in it, and also study critical issues encompassing its various dimensions.

Adding technologies into the education process does not simplify teaching and learning activities but only adds another dimension of complexity. The adoption of e-learning and computer based learning in teaching is a complex innovation in which many obstacles need to be overcome (Machado and Chung, 2015; Čudanov et al., 2012).

E-learning in education has seen unprecedented growth and issue concerning the implementation process has become a focus (Tshabalala et al., 2014). Implementation of E-learning technologies involves the careful assessment of numerous factors, such as hardware, software, budgetary decisions, support services and user attitudes, competencies and participation. Khan (2004) has developed a Framework for E-Learning which puts the instructional systems design and pedagogical issues in the context of a much wider and complex set of factors integrating the analysis of an organization's e-learning environment.

\section{E-learning framework}

According to Khan (2004), E-Learning Frankwork which can be used to capture an organization's inventory of e-learning by addressing issues encompassing the following eight dimensions of open and distributed learning environments:
1. Pedagogical: Refers to teaching and learning. This dimension addresses issues concerning content, audiences, goal and media analysis; design approach; organization and methods and strategies of e-learning environments.

2. Technological: Examines issues of technology infrastructure in e-learning environments. This includes infrastructure planning, hardware and software.

3. Interface Design: Refers to the overall look and feel of e-learning programs. The interface design dimension encompasses page and site design, content design, navigation, and usability testing.

4. Evaluation: Includes both assessment of learners, and evaluation of the instruction and learning environment.

5. Management: Refers to the maintenance of learning environment and distribution of information.

6. Resource Support: Examines the online support and resources required to foster meaningful learning environments.

7. Ethical: Relates to social and political influence, cultural diversity, bias, geographical diversity, learner diversity, information accessibility, etiquette, and the legal issues.

8. Institutional: Issues of administrative affairs, academic affairs and student services related to elearning.

\section{MyGuru and IMS system and its E-learning}

According to Khan, a success in e-learning platform or learning management system involve a systematic process of planning, designing, evaluating and implementing online learning environment where learning is actively fostered and supported. In my personal point of view, the platforms such as MyGuru and IMS which currently used in UPSI are actually brilliant software or package towards Elearning purposes. This is because the platform could serve for educators, learners, admin staff and even parents in the process of teaching and learning. At this moment, the most important issue is that how to encourage the use of MyGuru and IMS among UPSI staff. Thus, create the E-learning environment is vital in this stage.

When we discuss and evaluate E-learning tools (MyGuru and IMS), we need to focus on P3 Model (People - Process - Product). Furthermore, the discussion needed to spin out together with Elearning Framework by Khan (2004) in order to get understand and ensure whether the criteria for entire E-learning tool has been fulfilled and implemented.

In general, MyGuru is more likely to be meaningful to learners (students) as it is easily accessible, clearly organized, well written, authoritatively presented, learner-centred and flexible. Besides that, MyGuru also meaningful to academic staff (lecturers) when learners display a high level of participations and success in meeting a course's goals and objectives. For example, students 
can use E-forum to do discussion and answer the questions online. Student's involvement in Eassessment and E-portfolio has proven that MyGuru is a platform for UPSI students to get into the Elearning activities. For Support Services Staff, MyGuru and IMS also achieve its goals. Finally, MyGuru and IMS can be categorized as marvellous tools for encourage E-learning activities in UPSI and achieve high level of learner satisfaction with both quality of instruction and all support services. According to Mohd et al. (2014), MyGuru has been through some of the innovation process to ensure they are stable and effective systems in an effort to cultivate learning blended learning.

The innovations that have been done are as follows:

1. Integration of data - as part of the University Integrated Management System (UIMS), MyGuru has been fully integrated with other systems in the university and can be accessed through a single log-in.

2.E-portfolio - allowing students to manage and update the individual portfolio evidence of their learning.

3. E-Assessment - online evaluation of the academic staff at the end of the semester.

4. Evaluation of the university - the assessment program and university infrastructure through a poll of students.

5. Review lab - quality evaluation of industrial training through a poll of students.

6. The outcome-based education - building framework specific curriculum (taking into account aspects of soft skills, Bloom's taxonomy and so on).

7.Video Up-loader - allow students to upload video content to a cloud server (cloud server) and sharing among learning communities and

8. E-PBL - E-PBL able students to discuss activities related to problem based learning.

\section{Promoting continuing e-learning environment via MyGuru and IMS in UPSI}

As we know that technology itself could not or even impossible to develop an interesting and meaningful blended learning for teaching and learning. Integration of pedagogy in technology is vital for the success of MyGuru and IMS in teaching and learning. Academic staff (lecturers) play very important role in planning and designing stage that have been mentioned in P3 Model. Indeed, instructional designers and educators are understood that a successful integration of blended E-learning need consider various aspects.

According to Khan (2004), how well the instructional strategy used for each objective? Or how well are E-learning standards for interchangeability of learning objects used throughout the course? Or how good is the content? How well do learners interact with it? These are the questions need to be identified by academic staff during the planning and designing stage. In E- learning Framework by Khan also clearly noted that Pedagogical, Technological and Interface design should come first in any E-learning activities.

In my personal point of view, MyGuru and IMS which have been used in UPSI for years, is only in initial stage for promoting and introducing Elearning to students. This is most due to the reason that no compulsory for the academic staff to use the MyGuru and IMS system or software. Lecturers only use it when come to the needs such as apply for leaves, pay slip, apply housing loan, key in student's marks and etc. In conjunction with that, the management team of UPSI should encourage academic staff to explore more than what they need to do or use especially in development stage like what happen in UPSI. In P3 Model and E-learning Framework by Khan (2004) clearly mention that top management team should play their role when come to the development stage. Management team should ensure that staff in UPSI understands the University is very serious on implementing and promoting Elearning culture.

For Evaluation Stage, according to Khan (2004) in his E-learning Framework, the evaluation of Elearning including both the assessment of learners and evaluation of Instruction and learning environment. For MyGuru, assessment of learners again depend on lecturer's initiative whether they way to upload the assessment or test in the system. MyGuru has the marvellous platform for lecturer to do so. MyGuru itself would not able to show how many times entire student access MyGuru system directly. For second part, evaluation of Instructional and learning environment, yet depend on the academic staff (lecturer). Lecturers require creating learning environment such as E-form, E-portfolio, Eassignment and etc. in their daily teaching and learning activities. Staffs have to align with the fundamental values of E-learning features. UPSI's staff should create a Code of Ethics for E-learning and this endeavour begins with a top-down commitment. Dean and head of department should ensure all staff understands the importance of increasing the level of E-learning in UPSI. This may require greater number of faculty enforcing the policies, procedures or code.

For Delivery and Maintain Stage under MyGuru and IMS, it provides secure E-learning environment to lecturer (academic staff) and students in UPSI. MyGuru and IMS provide a personalized E-learning teaching and learning environment where lecturers can access online course and teaching tools. Lecturers have access to learner's data, student feedback and statistical data for research purposes. Lecturers also can design and create their own website that able to facilitate the teaching and learning. This is an addition to conventional teaching activities.

MyGuru also create initiate platform for Elearning to depart in UPSI. Students in UPSI able to access to online resources, communication and administration facilities such as register online and knowing their assignments, timetables, examination 
results and other asynchronous tools like email and E-forum and discussion.

\section{Discussion}

A well-designed E-learning tool can definitely provide numerous features conducive to learning. MyGuru and IMS are still in the initiate stage in encouraging UPSI staff and students to use Elearning in their teaching and learning. MyGuru and IMS are still in the beginning stage and have huge room to improve to reach quality and effectives Elearning tools.

In UPSI, MyGuru as the other of learning management system offers huge opportunity for Elearning activities but now the main concern it on the user themselves (Siti, 2014). In my personal point of view, many UPSI lecturers believe those internet resources as optional for teaching and learning and many instructional still through printed materials and face-to-face teaching method still as the primary choice for most of the lecturers in UPSI. They believe that conventional teaching methods can achieve better results. Due to this drawback, accesses to electronic and online participation among UPSI students become optional and voluntary.

For Resource Support, UPSI should work toward increasing its technology resources including computers link across the various campuses in Malaysia. Launching training sessions for all UPSI staff on the E-learning approach is vital to prepare them to utilize E-learning technology. UPSI top management needs provide supports both the instructors and learners in various ways (E-learning) by facilitating the design and development of instructional materials. Students in UPSI should attend formal orientation session on E-learning teaching and learning approach at the beginning of each academic year.

\section{Conclusion}

E-learning pedagogical practice is another pedagogy that needs to be highlighted in $21^{\text {st }}$ teaching and learning. Integrating E-learning in teaching and learning has been proven to have it contribution in students' performance and create higher order thinking skills. Having such knowledge and skills, students could meet the needs of the challenging world. Educators and policymakers should understand that by integrating e-learning in teaching and learning without understanding students' learning styles will not give any advantages to either educators or institutions. In order to avoid resistance of changes among educators in the use of blended learning or e-learning, a proper planning is vital before the implementation of e-learning or blended learning. Based on the interviewed users, most of them contended that MyGuru and IMS are brilliant software for integrating blended learning in teaching and learning among student-teachers. Indeed, student-teachers would have the opportunity to use and learn how to use learning management system and in future they might have higher motivation and urge to integrate blended learning in teaching and learning in school environments.

\section{References}

Alammary A, Sheard J and Carbone A (2014). Blended learning in higher education: Three different design approaches. Australasian Journal of Educational Technology, 30(4): 440-454.

Čudanov M, Savoiu G and Jaško O (2012). Usage of technology enhanced learning tools and organizational change perception. Computer Science and Information Systems, 9(1): 285-302.

Glenn AD and Carrier CA (1986). Teacher education and computer training: An assessment. Peabody Journal of Education, 64(1): 67-80.

Khan BH (2004). Comprehensive approach to program evaluation in open and distributed learning (CAPEODL) model. Introduced in the Program Evaluation Course. George Washington University, Washington.

Machado LJ and Chung CJ (2015). Integrating technology: The principals' role and effect. International Education Studies, 8(5): 43-53.

Mohd NMS, Ahmad WS and Megat AA (2014). Pembelajaran teradun in UPSI. In: E. Mohamed Amin (Eds), Blended and Flipped Learning: Case Studies in Malaysian HEIs (pp. 181-192), Centre for Teaching and Learning Technologies, Universiti Kebangsaan Malaysia and Department of Higher Education, Ministry of Education Malaysia, Bangi, Malaysia. Available online at: http://www.moe.gov.my/cms/upload_files/publi cationfile/2015/pubfile_file_002071.pdf

Siti NS (2014). Barriers influencing teacher' student technology integration in their teaching practice. Australian Journal of Basic and Applied Sciences, 8(23): 352-357.

Songkram N (2015). E-learning system in virtual learning environment to develop creative thinking for learners in higher education. Procedia-Social and Behavioral Sciences, 174: 674-679.

http://doi.org/10.1016/j.sbspro.2015.01.600

Tipton FB (2002). Bridging the digital divide in Southeast Asia: Pilot agencies and policy implementation in Thailand, Malaysia, Vietnam, and the Philippines. ASEAN Economic Bulletin, 19(1): 83-99.

Tshabalala M, Ndeya-Ndereya $C$ and van der Merwe $\mathrm{T}$ (2014). Implementing Blended Learning at a Developing University: Obstacles in the Way. Electronic Journal of e-Learning, 12(1): 101-110. 